\title{
The Determinant Factors of Muzakki Toward Paying Zakat, Infaq, Sedekah (ZIS) in Zakat Institutions
}

\author{
Hening Pratika Nila Hapsari ${ }^{1 *}$, Unggul Priyadi² \\ 1,2Faculty of Business and Economics, Indonesian Islamic University \\ * hening.pratika18@gmail.com
}

Article History

\begin{tabular}{lll}
\hline Received & $: 2020-07-22$ \\
\hline Revised & $: 2020-12-17$ \\
\hline Accepted & $: 2020-12-21$ \\
\hline
\end{tabular}

\section{Abstract}

Introductions to The Problem: Zakat is one of worship which is often mentioned in the Al Quran. It's just that the potential for Zakat, Infaq, Alms (ZIS) is not comparable to the actual figures. Many factors influence muzakki in paying ZIS.

Purpose/Objective Study: This study aims to analyze the factors that influence muzakki to pay ZIS in zakat institutions, namely Yatim Mandiri

Design/Methodology/Approach: The sample in this study amounted to 200 respondents. LAZ Yatim Mandiri was chosen because it is an Amil Zakat Institution that is consistent in collecting ZIS funds from the smallest amount to the large amount. This study uses logistic regression analysis and the data used are primary data. Based on the analysis that has been done, it is found that $61 \%$ results can be predicted correctly in the logistic regression model in this study.

Findings: The consistency of muzakki in paying ZIS at the Yatim Mandiri Amil Zakat Institution is influenced by the variables of religiosity, income, trust, shariah compliance, knowledge, justice, data publication, financial accountability, motivation, the role of ulama, the role of government. And the consistency of muzakki in paying ZIS at the Yatim Mandiri Amil Zakat Institution is not influenced by the variables of shariah compliance and financial accountability.

Paper Type: Research Article

Keywords: Determinant; Muzzaki; Zakat Institutions; ZIS.

Ihtifaz: Journal of Islamic Economics, Finance, and Banking
Journal of Islamic Economics,

Finance, and Banking

Vol. 3, No. 2, December 2020, pp. 143-158, ISSN p:2622-4755 e:2622-4798

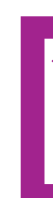

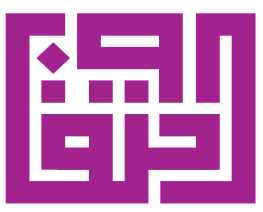

IHTIFAZ

UNIVERSITAS AHMAD DAHLAN

Kampus 4

Universitas Ahmad Dahlan Universitas Ahmad Dahlan
Il. Ringroad Selatan, Tamanan Banguntapan, Bantul Yogyakarta 55191 


\section{INTRODUCTION}

Islam is a religion brought by the last prophet, Prophet Muhammad IHTIFAZ - JIEFB SAW, in which there are comprehensive rules (syumul). Syumul which means that in Islam is not only about worship, but there is also empowerment of people who need or are less well off financially. This is done to prevent the existence of wealth inequality and aims to make society more prosperous, comfortable in living life and worship to Allah SWT. One of the instruments that regulates this is zakat. (Didin, 2002)

The obligation to pay zakat has been explained in the words of Rasulullah SAW, which means: From Abdullah ra, he said the Messenger of Allah said: "The religion of Islam is fostered in five cases: Confession (Creed) that there is no god but Allah, and Muhammad is His servant and His Messenger ; Establish Prayer; Paying Zakat; Ramadan fasting. " (HR. Muslim). Zakat already occupies the third position in the pillars of Islam. Zakat is also often mentioned in the Qur'an how important it is to carry out the three pillars of Islam. Allah SWT mentions that zakat is side by side with prayer services, although often people assume that worship which occupies the third position is fasting.

According to data from the Central Statistics Agency (BPS), in 2010 the country of Indonesia was one of the countries where the majority of the population were Muslim, amounting to $87.18 \%$ or around 207 million people. Data from BPS in 2017 Indonesia's poverty rate reached 27.77 million or $10.64 \%$. Therefore, to reduce the poverty rate faced by the Indonesian state, one of the Islamic Sharia laws is zakat. That is, zakat is one way that can be applied by the government to reduce poverty and social inequality that occurs in society.

Research data conducted by the National Amil Zakat Agency (BAZNAZ), that the potential for zakat in Indonesia is always increasing every year. In 2010 the potential for zakat obtained amounted to Rp 217 trillion and has always increased until 2016 reaching Rp 268 trillion. This figure proves that there is always an increase in potential in the collection of zakat in Indonesia, but the national zakat collected by LAZ only reached Rp 5.1 trillion or only about $1 \%$ of the existing zakat potential. Therefore, the collection of zakat funds at LAZ is still low.

The amount of zakat funds collected at LAZ Yatim Mandiri from 2017 to 2019 always shows an increase, where in May 2017 the collected zakat funds amounted to Rp 738,162,193 and Sedekah infaq funds amounted to $\mathrm{Rp} 6,716,695,092$. Then in May 2018 there was an increase in the amount of zakat funds collected amounting to Rp 1,244,068,193 and infaq Sedekah funds amounting to Rp 9,186,826,045. Furthermore, in May 2019 the zakat funds collected amounted to Rp 1,811,139,525 and Sedekah infaq funds amounted to Rp $13,673,876,035$.

Based on the explanation in the background above, the authors are interested in conducting research on how the influence of 
religiosity, income, trust, shariah compliance, knowledge Allah, fairness, publication, financial accountability, motivation, the role of scholars and the government towards consistency to pay for ZIS at the Amil Zakat Institution.

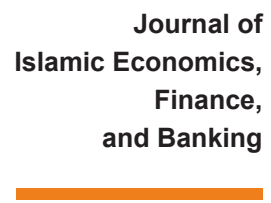

Vol. 3, No. 2, December 2020 , pp. 143-158, ISSN p:2622-4755 e:2622-4798

Islamic religion requires the fulfillment of the third pillar of Islam, namely zakat as the word of SWT in the QS. Al-Baqarah: 110. QS. AlBaqarah: 277. QS. At-taubah: 71, explains how important it is to pay Zakat. Consistency is defined as stability or determination in acting. Everyday life, consistency is needed that aims to increase the stability in doing various things that will make a habit. Consistency in this case is an attitude or action of someone in paying zakat which is continually improving and permanent, but the level of consistency of a person can be influenced by several factors. Paying zakat in Islam is an obligation that must be done if the assets owned have reached the limit of haul or Nisab. Consistency in paying ZIS is a form of consistency in the way of Allah SWT. Religiosity is related to individual attitudes in determining and choosing to participate in an Islamic financial institution (Priaji, 2011). According to Reksoprayitno (2004), income is the existence of receipts that can be valued in terms of a unit of currency that can be obtained by someone in a certain time.

This belief is interpreted as a belief in an individual or group's actions that are consistent in accordance with the trust they have. Because basically that this trust is formed from a belief that appears slowly in a process and this belief arises because of the recurring perception and is accompanied by experience (Rouf, 2011). Shariah compliance is an institution's adherence to shariah principles. Knowledge of zakat includes the definition of zakat, the obligation of zakat, ways of zakat, various types of zakat that will facilitate a person in paying zakat. That is, knowledge is the basis of the formation of a force for someone to do something they want (Kusmawati, 2011). The success of an amil zakat institution or body in providing muzakki satisfaction in paying zakat is justice in service, because fair service is a major factor for muzakki to be satisfied. Publication is an activity to introduce, announce and disseminate information to the public in various ways. According to Mardiasmo (2002), Accountability is an obligation of the party holding the mandate in providing responsibility, reporting, presenting and disclosing all activities and activities that are the responsibility of the trustee who has the rights and also the authority to hold that responsibility.

According to Adair (2007), the notion of motivation is everything that makes people able to do something, but the more important meaning of this word is that motivation is what makes people really try and also spend energy for what they can do. In Indonesia, the word 'ulama who become pious is generally interpreted as a knowledgeable 
person. The word ulama when connected with other words such as the Tafsir Ulama, Hadith Ulama and so on will have a broader meaning. IHTIFAZ - JIEFB The role of government has a large and significant role in managing social processes in society. The main task that must be carried out by the government is how to create a democratic life, provide a sense of peace and justice, and provide good social services so as to be able to bring its citizens to a place of prosperity.

\section{METHODOLOGY}

\section{Research population and data collection methods}

The population in this study is the general public who are Muslims and people who already have an income and have become muzakki at LAZ Yatim Mandiri. Taking the number of samples is determined based on the theory of Roscoe (1975), where taking a sample of more than 30 and less than 500 is appropriate if used as a study. So, the number of samples used in this study were 200 respondents, because this study was more than 30 and also less than 500 . The sampling technique in this study was using a purposive sampling technique. The data used in this study is to use primary data, by collecting data using questionnaires and using a five-point Likert scale that is strongly disagree (STS), disagree (TS), Neutral (N), agree (S) and strongly agree (SS) and then each answer will add up.

\section{Methods of analysis}

This research analysis technique uses descriptive and statistical analysis techniques. In the analysis technique to classify and also answer research objectives regarding consistency in paying for ZIS. Whereas in statistical analysis it is used for the purpose of testing the influence between variables used in this study. Each hypothesis was analyzed using SPSS 21.0 for Windows software to test the relationship between variables.

The analytical tool used in this study is logistic regression analysis. The understanding of logistic regression analysis is that it is used because of the consistency dependent variable which is a dummy variable. According to Ghozali (2013), when the logistic regression method is used there is no need for the assumption of normality in the independent variable. The assumption of multivariate normal distribution cannot be fulfilled, it is because the independent variable is a mixture of metrics and also non-metrics.

\section{RESULTS AND DISCUSSION}

Based on the results of the questionnaire obtained the characteristics of respondents described as follows: 
Table 1. Characteristics of Respondents by Gender

\begin{tabular}{|c|c|c|c|c|c|c|}
\hline & & Frequency & Percent & Valid Percent & $\begin{array}{c}\text { Cumulative } \\
\text { Percent }\end{array}$ & $\begin{array}{r}\text { Finance, } \\
\text { and Banking }\end{array}$ \\
\hline \multirow{3}{*}{ Valid } & Men & 128 & 64.0 & 64.0 & 64.0 & \multirow{3}{*}{$\begin{array}{r}\text { Vol. 3, No. 2, December 2020, } \\
\text { pp. 143-158, ISS p:2622-4755 } \\
\text { e:2622-4798 }\end{array}$} \\
\hline & Women & 72 & 36.0 & 36.0 & 100.0 & \\
\hline & Total & 200 & 100.0 & 100.0 & & \\
\hline
\end{tabular}

Source: Data already processed (SPSS 21.0 for Windows)

The data table above shows that the sexes are divided into two groups, male and female. Men with 128 respondents or $64 \%$ and women with 72 respondents or $36 \%$, total respondents in the study totaled 200 respondents.

Table 2. Characteristics of Respondents by Age

\begin{tabular}{|c|c|c|c|c|c|}
\hline & & Frequency & Percent & Valid Percent & $\begin{array}{l}\text { Cumulative } \\
\text { Percent }\end{array}$ \\
\hline \multirow{4}{*}{ Valid } & $18-25$ years & 15 & 7.5 & 7.5 & 7.5 \\
\hline & $26-40$ years & 100 & 50.0 & 50.0 & 57.5 \\
\hline & $41-60$ years & 85 & 42.5 & 42.5 & 100.0 \\
\hline & Total & 200 & 100.0 & 100.0 & \\
\hline
\end{tabular}

Source: Data already processed (SPSS 21.0 for Windows)

From the table above shows that the age of respondents was divided into 3 groups, namely the first age 18-25 years totaling 15 respondents or $7.5 \%$. Then the second age $26-40$ years amounted to 100 respondents or $50 \%$ and the third age 41-60 years amounted to 85 respondents or $42.5 \%$, the total respondents in the study numbered 200 respondents.

Table 3. Characteristics of Respondents Based on Education

\begin{tabular}{lrrrrr}
\hline & Frequency & Percent & \multicolumn{2}{c}{$\begin{array}{c}\text { Valid } \\
\text { Percent }\end{array}$} & $\begin{array}{c}\text { Cumulative } \\
\text { Percent }\end{array}$ \\
\hline \multirow{4}{*}{$\begin{array}{l}\text { Primary school - junior } \\
\text { high school }\end{array}$} & 50 & 25.0 & 25.0 & 25.0 \\
\cline { 2 - 6 } & Senior high school & 38 & 19.0 & 19.0 & 44.0 \\
\cline { 2 - 6 } & 97 & 48.5 & 48.5 & 92.5 \\
\cline { 2 - 6 } & Diploma - Bachelor & 15 & 7.5 & 7.5 & 100.0 \\
\cline { 2 - 6 } & Master - Professor & 200 & 100.0 & 100.0 & \\
\hline & Total & & &
\end{tabular}

Source: Data already processed (SPSS 21.0 for Windows) 
From the table above shows that the education of respondents was divided into 4 groups. First, elementary school and junior high school IHTIFAZ - JIEFB amounted to 50 respondents or $25 \%$, second high school totaled 38 respondents or $19 \%$. Furthermore, the third Diploma-S1 numbered 97 respondents or $48.5 \%$ and the fourth S2-S3 totaled 15 respondents or $7.5 \%$, the total respondents in the study numbered 200 respondents.

Table 4. Characteristics of Respondents Based on Employment

\begin{tabular}{llrrrr}
\hline & & Frequency & Percent & \multicolumn{2}{c}{ Valid } \\
Percent & $\begin{array}{c}\text { Cumulative } \\
\text { Percent }\end{array}$ \\
\hline \multirow{4}{*}{ Valid } & government employees & 33 & 16.5 & 16.5 & 16.5 \\
\cline { 2 - 6 } & private employees & 40 & 20.0 & 20.0 & 36.5 \\
\cline { 2 - 6 } & entrepreneur & 112 & 56.0 & 56.0 & 92.5 \\
\cline { 2 - 6 } & College student & 15 & 7.5 & 7.5 & 100.0 \\
\cline { 2 - 6 } & Total & 200 & 100.0 & 100.0 & \\
\hline
\end{tabular}

Source: Data already processed (SPSS 21.0 for Windows)

From the table above shows that the respondent's work is divided into 4 groups. First, civil servants numbered 33 respondents or $16.5 \%$, secondly private employees amounted to 40 respondents or $20 \%$. Furthermore, the third entrepreneur numbered 112 respondents or $56 \%$ and the fourth student numbered 15 respondents or $7.5 \%$, the total respondents in the study numbered 200 respondents.

Table 5. Characteristics of Respondents Based on Older be Muzakki in LAZ Yatim Mandiri

\begin{tabular}{cccccc}
\hline & Frequency & Percent & Valid Percent & $\begin{array}{c}\text { Cumulative } \\
\text { Percent }\end{array}$ \\
\hline \multirow{4}{*}{ Valid } & $<1$ years & 20 & 10.0 & 10.0 & 10.0 \\
\cline { 2 - 6 } & $1-2$ years & 30 & 15.0 & 15.0 & 25.0 \\
\cline { 2 - 6 } & $2-3$ years & 16 & 8.0 & 8.0 & 33.0 \\
\cline { 2 - 6 } & $>3$ years & 134 & 67.0 & 67.0 & 100.0 \\
\cline { 2 - 6 } & Total & 200 & 100.0 & 100.0 & \\
\hline
\end{tabular}

Source: Data already processed (SPSS 21.0 for Windows)

From the table above shows that old time became muzakki at LAZ Yatim Mandiri divided into 4 groups. First, less than 1 year amounted to 20 respondents or by $10 \%$, secondly $1-2$ years amounted to 30 respondents or by $15 \%$. Furthermore, the third $2-3$ years amounted to 16 respondents or $8 \%$ and the fourth more than 3 years totaled 134 respondents or $67 \%$, the total respondents in the study numbered 200 respondents. 
Table 6. Characteristics of Respondents by Type distributed to LAZ Yatim Mandiri

\begin{tabular}{|c|c|c|c|c|c|c|}
\hline & & Frequency & Percent & Valid Percent & $\begin{array}{c}\text { Cumulative } \\
\text { Percent }\end{array}$ & $\begin{array}{l}\text { inance, } \\
\text { 3anking }\end{array}$ \\
\hline \multirow{4}{*}{ Valid } & Zakat Maal & 12 & 6.0 & 6.0 & 6.0 & \multirow{4}{*}{$\begin{array}{r}\text { Vol. 3, No. 2, December 2020, } \\
\text { pp. 143-158, ISSN p:2622-4755 } \\
\text { e:2622-4798 }\end{array}$} \\
\hline & Infak & 66 & 33.0 & 33.0 & 39.0 & \\
\hline & Sedekah & 122 & 61.0 & 61.0 & 100.0 & \\
\hline & Total & 200 & 100.0 & 100.0 & & \\
\hline
\end{tabular}

Source: Data already processed (SPSS 21.0 for Windows)

The table above shows that the types distributed to LAZ Yatim Mandiri are divided into 3 groups. First, zakat maal is 12 respondents or $6 \%$, secondly infaq is 66 respondents or $33 \%$. Furthermore, the third Sedekah numbered 122 respondents or $61 \%$, the total respondents in the study numbered 200 respondents.

Table 7. Validity Test and Reliability Test

\begin{tabular}{|c|c|c|c|}
\hline Variables & Total Questions & $\begin{array}{l}\text { Value of } r \\
\text { Calculate }\end{array}$ & $\begin{array}{c}\text { Cronbach } \\
\text { Alpha }\end{array}$ \\
\hline \multirow{5}{*}{ Religiosity } & x1_1 & 0.952 & \multirow{5}{*}{0.979} \\
\hline & $x 2 \_2$ & 0.969 & \\
\hline & x3_3 & 0.959 & \\
\hline & $x 4 \_4$ & 0.969 & \\
\hline & x5_5 & 0.951 & \\
\hline \multirow{4}{*}{ Trust } & x1_1 & 0.946 & \multirow{4}{*}{0.963} \\
\hline & $x 2 \_2$ & 0.950 & \\
\hline & x3_3 & 0.954 & \\
\hline & x4_4 & 0.945 & \\
\hline \multirow{5}{*}{$\begin{array}{l}\text { Syariah } \\
\text { Compliance }\end{array}$} & x1_1 & 0.882 & \multirow{5}{*}{0.938} \\
\hline & $x 2 \_2$ & 0.888 & \\
\hline & x3_3 & 0.931 & \\
\hline & $x 4 \_4$ & 0.901 & \\
\hline & x5_5 & 0.874 & \\
\hline \multirow{4}{*}{ Knowledge } & $x 1 \_1$ & 0.954 & \multirow{4}{*}{0.962} \\
\hline & $x 2 \_2$ & 0.951 & \\
\hline & x3_3 & 0.947 & \\
\hline & $x 4 \_4$ & 0.940 & \\
\hline
\end{tabular}




\begin{tabular}{|c|c|c|c|c|}
\hline \multirow{3}{*}{ IHTIFAZ - JIEFB } & \multirow{4}{*}{ Justice } & x1_1 & 0.962 & \multirow{4}{*}{0.977} \\
\hline & & $x 2 \_2$ & 0.972 & \\
\hline & & x3_3 & 0.968 & \\
\hline & & $x 4 \_4$ & 0.969 & \\
\hline & \multirow{4}{*}{ Data Publication } & x1_1 & 0.925 & \multirow{4}{*}{0.952} \\
\hline & & $x 2 \_2$ & 0.939 & \\
\hline & & x3_3 & 0.947 & \\
\hline & & x4_4 & 0.931 & \\
\hline & \multirow{4}{*}{$\begin{array}{c}\text { Financial } \\
\text { Accountability }\end{array}$} & x1_1 & 0.902 & \multirow{4}{*}{0.924} \\
\hline & & $x 2 \_2$ & 0.899 & \\
\hline & & x3_3 & 0.911 & \\
\hline & & x4_4 & 0.897 & \\
\hline & \multirow{5}{*}{ Motivation } & x1_1 & 0.969 & \multirow{5}{*}{0.982} \\
\hline & & $x 2 \_2$ & 0.967 & \\
\hline & & x3_3 & 0.964 & \\
\hline & & $x 4 \_4$ & 0.960 & \\
\hline & & x5_5 & 0.966 & \\
\hline & \multirow{5}{*}{$\begin{array}{c}\text { The role of the } \\
\text { Ulema }\end{array}$} & x1_1 & 0.942 & \multirow{5}{*}{0.969} \\
\hline & & $x 2 \_2$ & 0.944 & \\
\hline & & x3_3 & 0.951 & \\
\hline & & $x 4 \_4$ & 0.939 & \\
\hline & & x5_5 & 0.937 & \\
\hline & \multirow{5}{*}{$\begin{array}{l}\text { Government>s } \\
\text { Role }\end{array}$} & x1_1 & 0.935 & \multirow{5}{*}{0.963} \\
\hline & & $x 2 \_2$ & 0.930 & \\
\hline & & x3_3 & 0.939 & \\
\hline & & x4_4 & 0.930 & \\
\hline & & x5_5 & 0.932 & \\
\hline
\end{tabular}

Source: Data already processed (SPSS 21.0 for Windows)

Based on the table above shows that the validity test on 200 respondents in all questionnaire items from the variables of religiosity, trust, shariah compliance, knowledge, fairness, data publication, financial accountability, motivation, the role of scholars and the role of government can be said to be valid. This can be proven from all items of questionnaire showing the value of sig 0,000 or sig $<0.05$. This means 
that some of the questionnaire items from the 10 variables above are said to be valid and suitable to be used as instruments in this study.

Based on the table above, the results show that the value of Cronbach's alpha on the variables of religiosity, trust, shariah compliance, knowledge, fairness, data publication, financial accountability, motivation, the role of scholars and the role of government shows the value of Croncach's Alpha> 0.6. That is, all instruments used in variables are reliable.

Table 8. Descriptive Statistics Test

\begin{tabular}{lrrrrr}
\hline & N & Minimum & Maximum & Mean & $\begin{array}{c}\text { Std. } \\
\text { Deviation }\end{array}$ \\
\hline Consistency (Y) & 200 & 0 & 1 & .61 & .489 \\
\hline Religiosity (X1) & 200 & 5 & 25 & 17.87 & 6.463 \\
\hline Income (X2) & 200 & 500000 & 9000000 & 2435125.00 & 1785307.107 \\
\hline Trust (X3) & 200 & 4 & 20 & 13.80 & 4.704 \\
\hline $\begin{array}{l}\text { Syariah Compliance } \\
\text { (X4) }\end{array}$ & 200 & 5 & 25 & 19.38 & 3.825 \\
\hline Knowledge (X5) & 200 & 4 & 20 & 15.09 & 4.174 \\
\hline Justice (X6) & 200 & 4 & 20 & 14.39 & 4.991 \\
\hline Data Publication (7) & 200 & 5 & 20 & 16.70 & 3.865 \\
\hline $\begin{array}{l}\text { Financial } \\
\text { Accountability (X8) }\end{array}$ & 200 & 4 & 20 & 15.69 & 3.087 \\
\hline Motivation (X9) & 200 & 5 & 25 & 19.22 & 5.755 \\
\hline $\begin{array}{l}\text { The role of the } \\
\text { Ulema (X10) }\end{array}$ & 200 & 5 & 25 & 17.46 & 4.687 \\
\hline $\begin{array}{l}\text { Government>s Role } \\
\text { (X11) }\end{array}$ & 200 & 5 & 25 & 20.60 & 4.652 \\
\hline \begin{tabular}{l} 
Valid N (listwise) \\
\hline
\end{tabular} & 200 & & & & \\
\hline
\end{tabular}

Source: Data already processed (SPSS 21.0 for Windows)

Overall statistical test results that the total sample used in this study amounted to 200 respondents. It is known that the minimum value of the religiosity variable is 5 and the maximum value is 25 . The average value of the religiosity variable is 17.87 with a standard deviation value of 6,463 . Then the minimum value of the income variable is 500,000 and the maximum value is $9,000,000$. The average value of income variable is $2,435,125$ with a standard deviation of $1,785,307$. The trust variable has a minimum value of 4 and a maximum value of 20 . The average value of the trust variable is 13.80 with a standard deviation of 4.704 .

It is known that the minimum value of the Shariah compliance variable is 5 and the maximum value is 25 . The average value of the Shariah compliance variable is 19.38 with a standard deviation value of 
3,825 . Furthermore, the minimum value of the knowledge variable is 4 and the maximum value is 20 . The average value of the knowledge IHTIFAL - JIEFB variable is 15.09 with a standard deviation value of 4.174 . The justice variable has a minimum value of 4 and a maximum value of 20 . The average value of the justice variable is 14.39 with a standard deviation value of 4.991. Furthermore, it is known that the minimum value of the publication variable is 5 and the maximum value is 20 . The average value of the publication variable is 16.70 with a stan It is known that the minimum value of the financial accountability variable is 4 and the maximum value is 20 . The average value of the financial accountability variable is 15.69 with a standard deviation of 3.087. The motivation variable has a minimum value of 5 and a maximum value of 25 . The average value of the motivation variable is 19.22 with a standard deviation value of 5.755. Furthermore, the minimum value of the ulama role variable is 5 and the maximum value is 25 . The average value of the ulama role variable is 17.46 with a standard deviation value of 4.687 . The government role variable has a minimum value of 5 and a maximum value of 25 . The average value of the government role variable is 20.60 with a standard deviation value of 4.652 dard deviation value of 3.865 .

Table 9. Model Fit Test (Overall Model Fit) Comparison of Initial $-2 \mathrm{LL}$ and Final -2LL

\begin{tabular}{cc}
\hline -2 Log Likehood & Score \\
\hline Early (Block Number : 0) & 267,499 \\
\hline End (Block Number : 1) & 94,157 \\
\hline
\end{tabular}

Source: Data already processed (SPSS 21.0 for Windows)

The test assesses the fit model using a value of -2 Log Likehood (-2LL). Based on table 4.17 for a consistent community sample the ZIS pay can be seen from the initial value of $-2 L L$ or block number: 0 is 267,499 and the value of -2 LL final or block number: 1 is 94,157 . The initial -2LL value is greater than the final -2LL value with a difference of value of 173,342 . Judging from the decrease in the value of $-2 \mathrm{LL}$, it can be concluded that the overall model is fit with the data.

Table 10. Omnibus Model Feasibility Test Results Tests of Model Coefficients

\begin{tabular}{llllll}
\hline & & & Chi-square & Df & Sig. \\
\hline \multirow{3}{*}{ Step 1 } & Step & 173.342 & 173.342 & 11 & .000 \\
\cline { 2 - 6 } & Block & 173.342 & 173.342 & 11 & .000 \\
\cline { 2 - 6 } & Model & 173.342 & 173.342 & 11 & .000 \\
\hline
\end{tabular}

Source: Data already processed (SPSS 21.0 for Windows) 
Based on testing the Omnibus Tests of Model Coefficients in table 10 shows that the significance value of 0.000 , which means that the value is $<\mathrm{a} 0.05$. While the results of the feasibility testing of the model with Hormer and Lemeshow are as follows:

Table 11. Hormer and Lemeshow Model Feasibility Test Results

\begin{tabular}{cccc}
\hline Step & Chi-square & df & Sig. \\
\hline 1 & 14.327 & 8 & .074 \\
\hline
\end{tabular}

Source: Data already processed (SPSS 21.0 for Windows)

Based on table 11 of the Hormer and Lemeshow test to test the feasibility of the research model used it can be seen the Chi-square value of 14.332 with sig values. 0.074 , meaning that the value $>$ a 0.05 . From these results it can be concluded that the research model is feasible to use for testing in this study.

Table 12. Determination Coefficient Test Results

\begin{tabular}{cccc}
\hline Step & -2 Log likelihood & $\begin{array}{c}\text { Cox \& Snell R } \\
\text { Square }\end{array}$ & Nagelkerke R Square \\
\hline 1 & $94.157^{\mathrm{a}}$ & .580 & .786
\end{tabular}

Source: Data already processed (SPSS 21.0 for Windows)

Based on the results of table 12, it can be seen that the Nagelkerke $R$ Square value is 0.786 . Nagelkerke R Square is a modification of the Cox \& Snell R Square coefficient. The value of Nagelkerke R Square shows that the consistency of muzakki in paying ZIS is influenced by religiosity, income, trust, Shariah compliance, knowledge, fairness, data publication, financial accountability, motivation, the role of ulama and the role of government that is $78.6 \%$. While there are $21.4 \%$ explained by other variables not examined.

Table 13. Classification Table

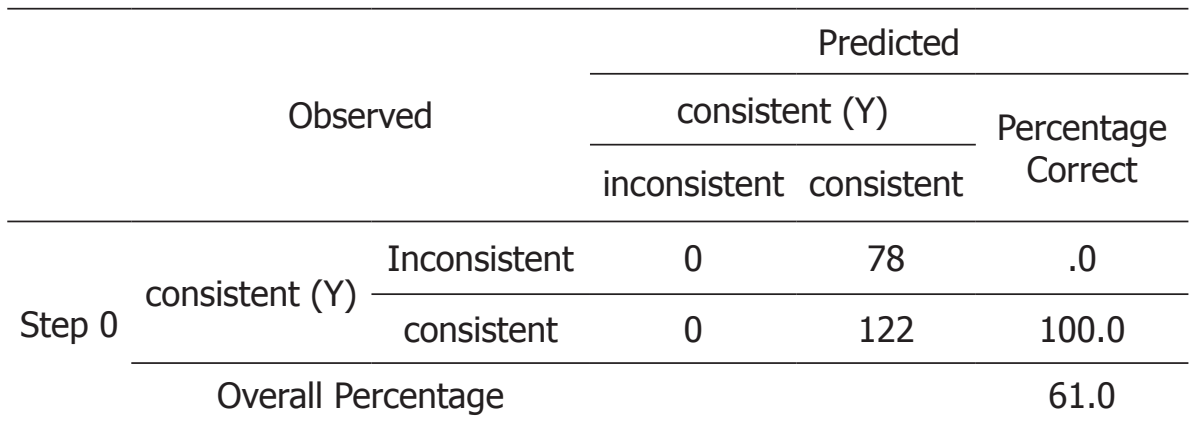

Source: Data already processed (SPSS 21.0 for Windows) 
Table 13 shows that of the 200 respondents and those who did not consistently pay ZIS at LAZ Yatim Mandiri at 78 respondents, $0 \%$ were able to be predicted accurately by the logistic model. While those who consistently pay ZIS at LAZ Yatim Mandiri totaling 122 respondents, it should be $100 \%$ predictable by the logistic regression model correctly. Overall, there are $61 \%$ that can be predicted accurately in the logistic regression model in this study.

Table 14. Hypothesis testing

\begin{tabular}{lcccc}
\hline \multicolumn{1}{c}{ Variables } & B & Sig. & Exp(B) & information \\
\hline Religiosity & .287 & .001 & 1.332 & significant \\
\hline Income & .000 & .041 & 1.000 & significant \\
\hline Trust & .218 & .010 & 1.243 & significant \\
\hline Syariah Compliance & -.147 & .086 & .863 & not significant \\
\hline Knowledge & .170 & .047 & 1.186 & significant \\
\hline Justice & .163 & .028 & 1.177 & significant \\
\hline Data Publication & .284 & .045 & 1.328 & significant \\
\hline Financial & -.140 & .128 & .869 & not significant \\
Accountability & .119 & .048 & 1.127 & significant \\
\hline Motivation & .160 & .021 & 1.174 & significant \\
\hline The role of Ulema & .139 & .049 & 1.149 & significant \\
\hline Government's Role & -21.685 & .000 & .000 & \\
\hline Constant & & & &
\end{tabular}

Source: Data already processed (SPSS 21.0 for Windows)

Religiosity variable has a coefficient value of 0.287 with a positive coefficient direction and sig value. $0.001<a 0.05$. So it can be concluded that the religious factor has a positive effect on the consistency of paying ZIS at LAZ Yatim Mandiri. Then according to $\mathrm{H} 1$ or $\mathrm{H} 1$ is accepted. The income variable has a coefficient value of 0,000 with a positive coefficient direction and a sig value. $0.041<\mathrm{a} 0.05$. So, it can be concluded that the income factor has a positive effect on the consistency of paying ZIS at LAZ Yatim Mandiri. Then according to $\mathrm{H} 2$ or $\mathrm{H} 2$ is accepted. The trust variable has a coefficient value of 0.281 with a positive coefficient direction and a sig value. $0.010<a 0.05$. So, it can be concluded that the trust factor has a positive effect on the consistency of paying ZIS at LAZ Yatim Mandiri. Then in accordance with H3 or H3 accepted.

Shariah compliance variable has a coefficient value of -0.147 with a value of sig. $0.086>$ a 0.05 . So, it can be concluded that the Shariah compliance factor does not affect the consistency of paying ZIS at LAZ Yatim Mandiri. Then according to $\mathrm{H} 4$ or $\mathrm{H} 4$ is rejected. The knowledge variable has a coefficient value of 0.170 with a positive coefficient direction and a sig value. $0.047<\mathrm{a} 0.05$. So, it can be concluded that the knowledge factor has a positive effect on the consistency of paying ZIS at LAZ Yatim Mandiri. Then according to H5 or H5 is accepted. The 
justice variable has a coefficient value of 0.163 with a positive coefficient direction and a sig value. $0.028<\mathrm{a} 0.05$. So, it can be concluded that the factor of justice has a positive effect on the consistency of paying ZIS at LAZ Yatim Mandiri. Then according to $\mathrm{H} 6$ or $\mathrm{H} 6$ is accepted. The publication variable has a coefficient value of 0.284 with a positive coefficient direction and a sig value. $0.045<\mathrm{a} 0.05$. So, it can be concluded that the publication factor has a positive effect on the

Journal of Islamic Economics, Finance, and Banking

Vol. 3, No. 2, December 2020, pp. 143-158, ISSN p:2622-4755 e:2622-4798 consistency of paying ZIS at LAZ Yatim Mandiri. Then according to H7 or $\mathrm{H} 7$ is accepted.

The variable of financial accountability has a coefficient value of -0.140 with a value of sig. $0,128>$ a 0,05 . So, it can be concluded that the factor of financial accountability does not affect the consistency of paying ZIS at LAZ Yatim Mandiri. Then according to $\mathrm{H} 8$ or $\mathrm{H} 8$ is rejected. The motivation variable has a coefficient value of 0.119 with a positive coefficient direction and a sig value. $0.048<a 0.05$. So it can be concluded that the motivational factor has a positive effect on the consistency of paying ZIS at LAZ Yatim Mandiri. Then according to H9 or $\mathrm{H} 9$ accepted. The role of the ulama variable has a coefficient value of 0.160 with a positive coefficient direction and a sig value. $0.021<\mathrm{a} 0.05$. So, it can be concluded that the role of scholars has a positive effect on the consistency of paying ZIS at LAZ Yatim Mandiri. Then according to $\mathrm{H} 10$ or $\mathrm{H} 10$ accepted. Government role variable has a coefficient value of 0.139 with a positive coefficient direction and sig value. $0.049<\mathrm{a} 0.05$. So, it can be concluded that the government's role factor has a positive effect on the consistency of paying ZIS at LAZ Yatim Mandiri. Then according to $\mathrm{H} 11$ or $\mathrm{H} 11$ is accepted. The first hypothesis is accepted, because it is likely that the high level of community religiosity will affect the consistency in paying for ZIS. That is, a high level of religiosity is also supported by an understanding of the obligation to pay zakat and can balance between material and religious values.

The second hypothesis is accepted, because income has a close relationship with whether the asset has reached Nisab or not, meaning that income affects the amount of ZIS issued by muzakki. The third hypothesis is accepted, because it is likely that when the level of public trust in an amil zakat institution, the more consistency in paying ZIS in the institution. The public will have more confidence in amil zakat institutions in managing funds collected according to the Shariah. The fourth hypothesis is rejected, because it is possible that although the application of shariah compliance in the management of zakat is a necessity, it is not related to the consistency of muzakki in paying ZIS at the amil zakat institution. However, what is more seen from muzakki in paying ZIS at the Amil zakat Institution is that it involves the responsibility of muzakki as a servant in carrying out Islamic law. The fifth hypothesis is accepted, because the importance of knowing zakat management carried out by an amil zakat institution is able to 
attract the public in channeling a portion of their income to pay zakat, infaq and Sedekah. The community will be more consistent in paying IHTIFAZ - JIEFB

ZIS when the public is aware of the amil zakat institutions in managing funds collected according to Shariah. The sixth hypothesis is accepted, because muzakki will be satisfied with the existence of fair and equal treatment to all parties carried out by the Amil Zakat Institution. The satisfaction of muzakki can be incurred because of the existence of the Zakat Institution to make some rules that can protect the interests of all parties, regulations in the implementation of the managing institution and also some policies that can protect the Institution from bad actions in the Institution, and also conflict of interests, and apply the responsibilities and roles of the Institute amil zakat.

The seventh hypothesis is accepted, because it is likely that the more data publication is done by an amil zakat institution, the public will be encouraged to pay zakat, infaq and Sedekah and make the public aware of the obligation to pay zakat so that it affects the consistency in paying ZIS. The eighth hypothesis is rejected because of the possibility that the accountability carried out by an amil zakat institution such as planning, compilation, and implementation is not necessarily known to the public. Therefore, the public does not feel compelled to pay zakat and does not affect consistency in paying ZIS. The ninth hypothesis is accepted, because the higher the motivation factor of the community will be motivated to pay zakat, infaq and Sedekah so that it creates consistency in paying ZIS at the Amil zakat Institution. The tenth hypothesis was accepted, because with the ulama conveying the importance and obligation of setting aside part of his wealth for zakat, so that the community was motivated to issue zakat. Therefore, people who are aware of the importance of tithing and distributing ZIS to the Amil Zakat Institution, will influence the consistency in paying ZIS. The eleventh hypothesis was accepted, because if the higher the government's role in motivating, conducting socialization and various policies carried out by the government to the public to pay zakat, then the community would be motivated by the importance of paying ZIS.

\section{CONCLUSION}

Characteristics based on sex that is equal to $64 \%$ men and $36 \%$ women. Characteristics based on the highest age are $26-40$ years at $50 \%, 41-60$ years at $42.5 \%$ and $18-25$ years at $7.5 \%$. The characteristics based on the highest education are Diploma-S1 at 48.5\%, High School at $19 \%$, Elementary-Junior High School 25\% and S2-S3 7.5\%. The characteristics based on the highest occupation are entrepreneurs by $56 \%$, private employees by $20 \%$, civil servants by $16.5 \%$ and students $7.5 \%$. Characteristics based on the length of time being muzakki in LAZ Yatim Mandiri the highest is $>3$ years by $67 \%, 2-3$ years by $8 \%, 1-2$ years by $15 \%$ and $<1$ year by $10 \%$. The characteristics based on the 
type that are distributed to the highest independent Amil Zakat Institute are Sedekah by $61 \%$, infaq for $33 \%$ and maal zakat by $6 \%$.

The results of the calculation and analysis of data using logistic regression shows that the opportunity for muzakki's consistency in paying ZIS at Amil Zakat Institution is above $50 \%$. Going forward, the

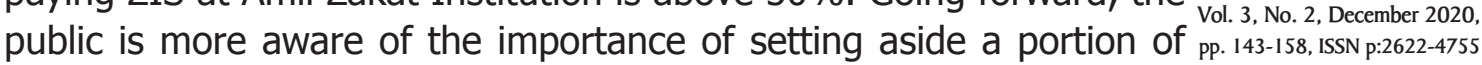
assets for zakat, infaq or Sedekah.

Simultaneous muzakki's consistency in paying ZIS at the Amil Zakat Yatim Mandiri Institution is influenced by variables of religiosity, income, trust, shariah compliance, knowledge, fairness, data publication, financial accountability, motivation, the role of scholars, the role of government. Partially, the consistency of muzakki in paying ZIS at the Amil Zakat Yatim Mandiri Institution is not influenced by shariah compliance and financial accountability variables.

\section{SUGGESTIONS}

It is expected that the Amil Zakat Institution will pay more attention to the factors that influence the consistency of muzakki in channeling part of its income to pay zakat, infaq and Sedekah in order to increase the consistency of muzakki. It is expected for further researchers to increase the number of samples and also add research variables beyond the variables studied in order to make further research better. It is hoped that further researchers will be able to develop existing research models.

\section{REFERENCES}

Adair, John. 2007. Pemimpin yang Berpusat pada Tindakan. Binarupa Aksara, Jakarta.

Al-Qur'an dan Terjemahannya.

Badan Amil Zakat Nasional, 2016. Data Lembaga Amil Zakat Di Indonesia. Jakarta: 2016.

Badan Pusat Statistik Jakarta Pusat, 2017. Statistik Indonesia Tahun 2017. Jakarta Pusat: Badan Pusat Statistik.

Didin Hafidhhudin, Zakat Dalam Perekonomian Modern, Jakarta: Gema Insani, 2002, h. 7.

Ghozali, Imam, 2013. Aplikasi Analisis Multivariate dengan program IBM SPSS 21 Update PLS Regresi. Semarang: Badan Penerbit Universitas Diponegoro.

Kusmawati, 2011. Pengaruh motivasi terhadap Minat Berinvestasi di Pasar Modal Syariah. Jakarta: Kencana Prenada Media Group.

Mardiasmo. 2002. Akuntansi Sektor Publik. Yogyakarta: Andi.

Prihaji, dkk. 2011. "Faktor-Faktor yang Mempengaruhi Intensi Menabung di Bank Syariah". Skripsi. Universitas Islam Negri Syarif Hidayatullah Jakarta. 
Reksoprayitno. 2004. Sistem Ekonomi dan Demokrasi Ekonomi. Jakarta: Bina Grafika, 2004. Hal. 79.

IHTIFAZ - JIEFB

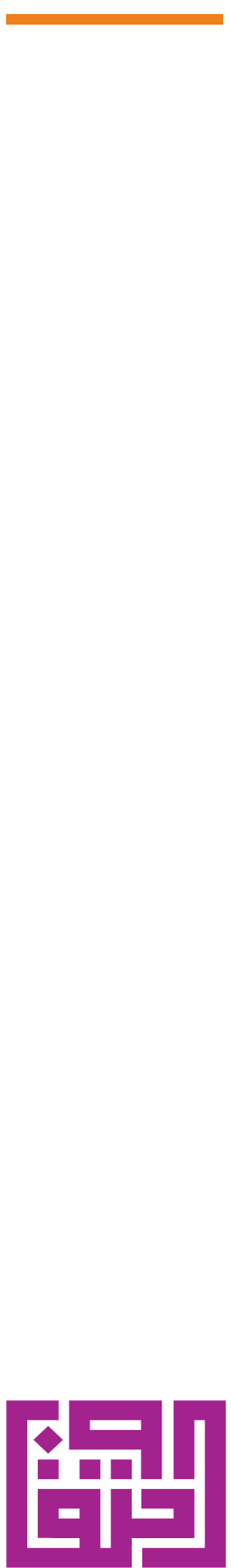

IHTIFAZ

UNIVERSITAS AHMAD DAHLAN

Kampus 4

Universitas Ahmad Dahlan J. Ringroad Selatan, Tamanan Banguntapan, Bantu e-mail : ihtifaz@uad.ac.id
Roscoe, J. T (1975). Fundamental Research Statistics for The Behavioural Sciences. ( $2^{\text {nd }}$ ed). New York: Holt Rinehart \& Winston.

Rouf, M.A. 2011. "Analisis Faktor faktor yang Mempengaruhi Minat Muzakki untuk Membayar Zakat di Rumah Zakat Cabang Semarang," Skripsi. Institut Agama Islam Negeri Walisongo Semarang.

Rulian, Anggraeni, Lubis, 2013. "Analisis faktor-faktor yang mempengaruhi muzakki dalam memilih organisasi pengelolaan zakat (OPZ)". Jurnal Al-Muzara'ah, Vol. 3, No.1 (ISSN p:2337-6333; e:2355-4363).

Sri Nurhayati. 2015. Akuntansi Syariah di Indonesia. Jakarta: Salemba Empat.

Sugiyono. 1999. Metodologi Penelitian Administrasi. Edisi Kedua. Bandung: CV Alfa Beta.

Sugiyono. 2010. Metode Penelitian Bisnis. Bandung: Alfabeta.

Susmeni, 2017. "Faktor-Faktor yang Berpengaruh Terhadap Konsistensi Muzakki untuk Membayar Zakat Maal di Lembaga Amil Zakat". Skripsi. Universitas Muhammadiyah Yogyakarta.

Swari, G.P.A. 2014. "Faktor-Faktor yang Mempengaruhi Konsistensi Muzakki dalam Membayar Zakat Maal (Studi Kasus pada Muzakki di BAZDA Wonogiri)." Skripsi. Universitas Islam Negri Sunan Kalijaga Yogyakarta.

Undang-Undang Pasal 34 ayat (1) tentang mengamankan kewajiban negara untuk memelihara fakir miskin dan anak terlantar.

Waluyo, Agus. 2016. "Kepatuhan Bank Syariah terhadap Fatwa Dewan Syariah Nasional Pasca Transformasi ke dalam Hukum Positif". Jurnal Penelitian Sosisal Keagamaan, Vol. 10, No. 2 Hal. 517-538.

Wikaningtyas, S.U dan Sulastiningsih. 2015. "Strategi Pengumpulan Zakat pada OPZIS Daerah Istimewa Yogyakarta dalam Upaya Pengentasan Kemiskinan" Syariah Paper Accounting. Universitas Muhammadiyah Surakarta.

Yatim Mandiri, 2019. Data dan Informasi Keuangan Tahun 2019. http:// yatimmandiri.org/, diakses pada tanggal 15 Oktober 2019.

Yupitri,E dan Raina L.S. 2012. "Analisis Faktor faktor yang Mempengaruhi Non-Muslim Menjadi Nasabah Bank Syariah Mandiri di Medan". Jurnal Ekonomi dan Keuangan Vol.1 No.1.

Zakaria Bahari, 2017. "The Relationship between Income Household and Intention to Pay Zakat on Income among Indonesian Academicians". Mediterranean Journal of Social Sciencess, Vol. 8 No. 4 Juli 2017. 